\title{
Influences of Domestic Communication on Energy Conservation Behavior
}

\author{
Kota NAKAJIMA ${ }^{*}$, Hiroki HONDO ${ }^{1 \dagger}$, Katsumasa IHARA ${ }^{2}$, and Junichi KiKUi ${ }^{3}$ \\ (Received August 20, 2018)
}

\begin{abstract}
家庭内のコミュニケーションが省エネルギー行動に与える影響
中島光太 ${ }^{* 1}$, 本藤祐樹 ${ }^{1 \dagger}$, 伊原克将 ${ }^{2}$, 菊井順一 33
\end{abstract}

\begin{abstract}
The objective of the present study is to reveal the influences of domestic communication on energy conservation behavior in daily life. The Ministry of the Environment, Japan implemented the "Uchi-Eco-Shindan" Project in 2011, which provides households with environmental consulting services. In the present study, questionnaire surveys including questions about the situation of domestic communication (e.g. whether they talk about home-appliance replacement for energy conservation with their family members after "Uchi-EcoShindan") are conducted with 613 households that were provided with "Uchi-Eco-Shindan." The available data (254 out of 613 households) is analyzed using statistical methods. The analysis finds the possibility that households' electricity consumption after "Uchi-Eco-Shindan" is influenced by the two types of domestic communication, that is, to talk about replacement of appliances to reduce electricity consumption and to warn each other about energy conservation behavior. The present study suggests that domestic communication promotes energy conservation behavior in daily life, and concludes that more detailed analysis is necessary in the future.
\end{abstract}

本研究の目的は，日常生活の省エネルギー行動において，家庭内のコミュニケーションの影響を明らかにすることである。 環境省は，各世帯に対して環境コンサルティングサービスを提供する「うちエコ診断」事業を平成 23 年度に実施した。本 研究では,「うちエコ診断」を受診した 613 世帯に対し，家庭内のコミュニケーションの状況に関する質問 (例：うちエコ診 断受診後における省エネルギーのための家電の買い替えに係る家族との相談の有無）を含んだアンケート調査を実施してい る。そして, 統計的手法を用いて, 利用可能なデー夕（613 世帯のうち254 世帯）を対象に分析を行っている。分析の結果, 買替行動について家族と相談することや，日常的な省エネ行動について世帯員同士で注意し合うことが，うちエコ診断受診 後の電力変化量に影響を与える可能性を見い出している。本研究は, 家庭内コミュニケーションが日常生活の省エネルギー 行動を促進する可能性を示しており, 今後, より詳細な分析を行う必要性を指摘している。

\section{Key Words}

Domestic communication, Energy conservation behavior, Energy consumption,

Household, Questionnaire survey

\footnotetext{
※1 Yokohama National University

79-7 Tokiwadai, Hodogaya-ku, Yokohama-shi, Kanagawa 240-8501, Japan

※2 Deloitte Tohmatsu Consulting 2-4-1 Marunouchi, Chiyoda-ku, Tokyo 100-6390, Japan

※3 (Former) Japan Network for Climate Change Actions Daiichi Amai Building 4F, 1-12-3, Kanda Nishikicho, Chiyoda-ku, Tokyo 101-0054, Japan

$\uparrow$ Corresponding author: hondo@ynu.ac.jp
}

\footnotetext{
※ 1 横浜国立大学大学院 環境情報学府 / 環境情報研究院 干 240-8501 神奈川県横浜市保土ヶ谷区常盤台 79-7

※2 デロイトトーマツコンサルテイング合同会社 テ 100-6390＼cjkstart東京都千代田区丸の内 2-4-1 丸の内ビルデイング

※3（元）一般社団法人 地球温暖化防止全国衤卡 厂 101-0054 東京都千代田区神田錦町 1-12-3 第一アマイビル 4 階
} 


\section{1. はじめに}

近年深刻化する地球温暖化の防止においては, 家庭から 排出される温室効果ガスの削減が不可欠である。世帯人数 やその構成, 年収, 居住地域などが異なる多種多様な家庭 に対して, 省エネルギー行動 (以下, 省エネ行動とする) を 促進していくためには, 家庭に打ける省エネ行動の実施が, どのような要件により規定されているかについて明らかにす る必要がある。

家庭の省エネルギー化に関する研究は，欧米を中心に数 多く行われており，対象の家庭に対して省エネ行動促進のた めの介入を実践し，その前後のエネルギー消費の変化を分 析することで, 介入の効果を検証している1) 3)。ここで言う 介入の具体例としては, 省エネ行動の実施がもたらす電力削 減効果などの情報提供, 省エネルギーに向けた取組結果の フィードバックなどが挙げられる。また, 介入の効果の持続 性について着目する研究も行われている ${ }^{4)}$ 。 Abrahamse ら 5) は, 上記を踏まえた 1977 年から 2004 年までの 38 の既往研 究について, その研究手法や結論等を集約している。これ らの既往研究から, 家庭で実施できる省エネ行動に関する 情報提供や, 電力削減に向けた目標設定, 省エネ行動の実 施効果のフィードバックなどが効果的であることが明らかと なっている。また，それらの介入に対しては，年収が高い 世帯, また，世帯員が少ない世帯の方が影響を受けやすい 傾向にあることが指摘されている6)。

上記のような，家庭に対して省エネ行動を促進するため の介入の一つとして, 各々の家庭に扔ける世帯属性やエネル ギー需要を踏まえて有効な省エネ対策をアドバイスする，家 庭用エネルギー診断がある。日本においては, 八木田・岩船 7) が, 家庭用エネルギー診断による効果の検証を行い, 診断 前に電力消費量が小さい世帯の方が, 診断による効果が大 きかったことなどを指摘している。この研究では, 電力消費 量大の世帯に対する診断の効果が小さかった要因として, 家 族が省エネ行動に非協力的であったと考察している。他の既 往研究に打いても, 家庭において省エネ行動を実施するため には, 他の世帯員の参加・協力が要求されることや，その実 施を継続するためには，世帯員同士が技互いに実施を促した り，未実施の場合に注意し合ったりする行為が必要となるこ とが言及されている。例えば Gram-Hanssen ${ }^{8)}$ は, デンマー クの約 8,500 世帯の世帯属性, 電力消費量等に係る統計デー 夕を用いた分析を行い，世帯人数が多いほど一人当たりの電 力消費量が低いとの分析結果について，世帯人数が多い世 帯は, 複数の人々が共に生きるために家庭のエネルギー消費 について話し合うようになることを示唆している。このように, 家庭への省エネ行動の促進にあたっては, 対象の家庭に住 まう世帯員同士のコミュニケーションの状況 (省エネ行動の 実施方法に関する他の世帯員との相談の有無等, 以下, 家 庭内コミュニケーションとする) を考慮する必要があると言え る。しかし, 著者の知る限りでは, 家庭内コミュニケーショ ンの影響について，実測值に基づき統計的に検討した研究 は見当たらない。
本研究の目的は, 家庭内コミュニケーションが, 家庭にお ける日常生活の省エネルギー行動の実施に影響を与えている か否かを明らかにすることである。

\section{2. 方 法}

\section{1 うちエコ診断}

家庭への省エネ行動の促進に向け環境省では, 平成 23 年度から 25 年度までの事業として, 所定の診断員が一般の 世帯に対し, 専用ソフトウェアを用いて, 各世帯の電力消費 量等の実態に応じた有効な省エネ行動についてアドバイスす る「うちエコ診断」事業を実施した ${ }^{9)}$ 。

図1に, うちエコ診断の流れを示す。うちエコ診断の受診 世帯は, 診断前に, 事前調査により世帯の基本情報や電力 消費量等の使用状況の調査を受ける。次に診断員がその世 帯を訪問し, 専用ソフトウェアを用いて, 事前調査の内容を 基にあらかじめ算出しておいた結果を見せながら, $\mathrm{CO}_{2}$ 削減 に効果的な省エネ行動を提案する。そこで受診世帯は, 実 行可能な省エネ行動を選択する。診断から 1,2 ケ月後, 受 診世帯は, 提案を受けた省エネ行動の実施状況などについ て事後調査を受ける。

なお, 本研究では, 平成 23 年度の「うちエコ診断」事業 に扮ける本来の調査項目 (上述した世帯の基本情報や省工 ネ行動の実施状況など）に, 環境省の協力を得て, 家庭内 コミュニケーションに係る調査項目を追加して戴き, 必要な データを収集した。

\section{2 対象世帯}

本研究では, 平成 23 年度にうちエコ診断を受診した約 5,000 世帯のうち, HEMSが設置された 613 世帯を対象とし た。後述するように, 613 世帯のデータを精査し, 有効デー 夕を有し，世帯人数が二人以上である 254 世帯のデー夕を分 析に用いた。

\section{3 取得データ}

表1に示すように，うちエコ診断の事前・事後における質 問紙調査と, HEMSによる電力消費量調査によって, 各種デー 夕を取得した。各データの詳細については以下のとおりであ る。

\subsection{1 世帯属性}

うちエコ診断受診の事前調査では, 対象世帯の基本情報 を取得している。そのうち, 本研究では, 既往研究 6) 8)に おいて電力消費量を規定するとされている世帯年収及び世帯 人数を分析に用いた。

\subsection{2 受診後の省エネ行動の実施状況}

うちエコ診断で対象とされている省エネ行動は全 67 項目 あり, それらは, 買替行動 25 項目と, 日常的な省エネ行動 42 項目に大別される。日常的な省エネ行動についてはさらに, エアコン等に関する 12 項目, 照明・テレビ等に関する 9 項目, 給湯に関する 5 項目, 台所に関する 6 項目, その他の 10 項 目で構成されている。 


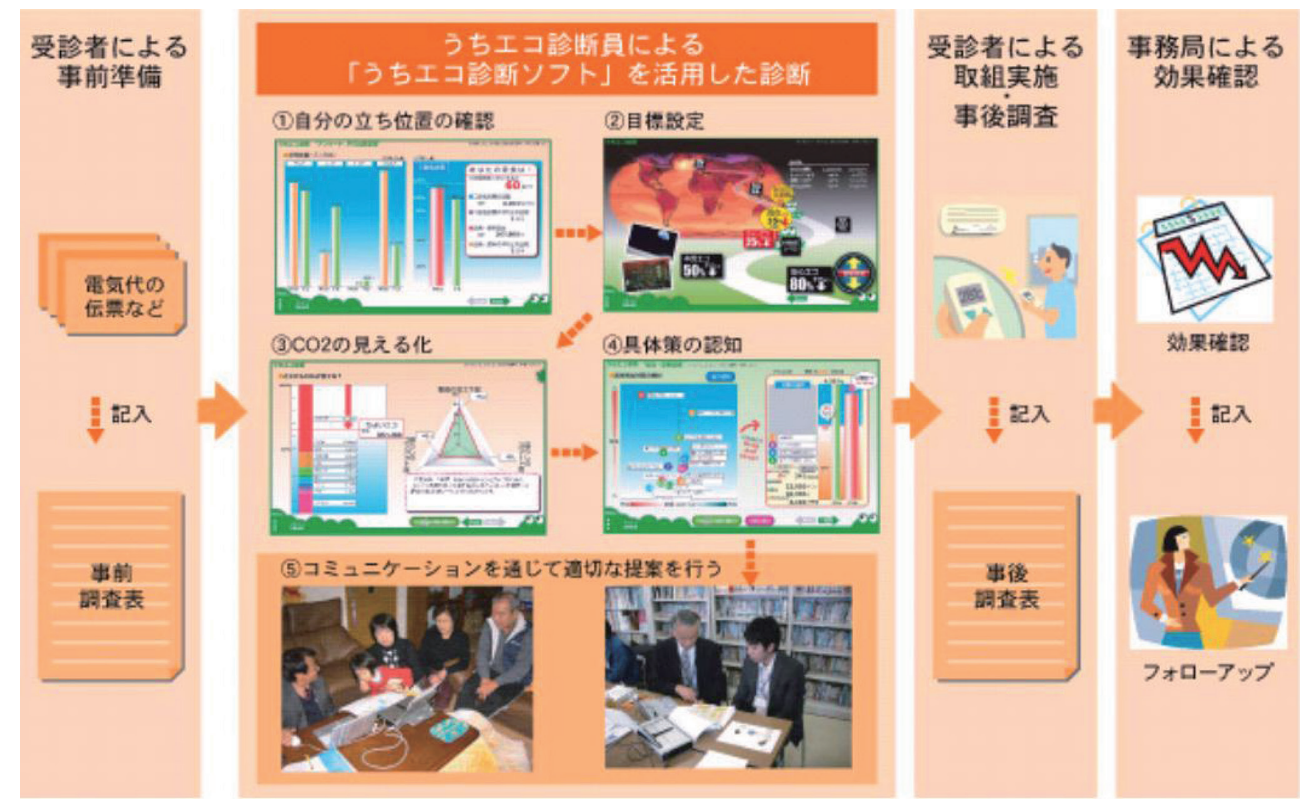

図1 うちエコ診断の実施フロー9)

\section{表1 調査の概要}

\begin{tabular}{l|l}
\hline 事前調査 & ·世帯属性 (世帯人数, 年収 など) \\
\hline 事後調査 & ·環境配慮行動の実施状況 \\
& ·家庭内コミュニケーションの状況 \\
\hline 電力消費量調査 & ·電力消費量 $(\mathrm{HEMS*によるログデータ)}$ \\
\hline
\end{tabular}

* House Energy Management System

受診後 1,2 か月後の事後調査において, 上記 67 項目の 省エネ行動の診断受診後における実施状況についてデー夕 を取得した。

\subsection{3 受診後の家庭内コミュニケーションの状況}

対象世帯の家庭内コミュニケーションの状況については, 事後調査により，以下の（1）～(5) の質問項目に対する回答 を取得した。設問項目は，うちエコ診断における省エネ行動 が，買替行動と日常的な省エネ行動に大別されていることを 踏まえ，(1) は診断内容全体について，(2) は買替行動につい て，（3）（5）は日常的な省エネ行動についての質問とした。 〔質問内容〕

うちエコ診断を受けた後のことについてお聞きします。

(1) うちエコ診断の診断内容を，他の同居の方（ご家族な ど）一人以上に伝えましたか?

(2) ご家庭内 (ご家族以外の同居している方も含む) にお いて，家電などの買い替えについて相談しましたか?

(3) ご家庭内 (ご家族以外の同居している方も含む)にお いて,「コンセントからプラグを抜き, 待機電力を減らす」 などの日常的な省エネ行動にどのように取り組むかに ついて相談しましたか?

(4) ご家庭内 (ご家族以外の同居している方も含む) で日 常的な省エネ行動をきちんと実施するように，同居の 方 (ご家族など) 同士で注意し合う機会は，診断前に くらべてどのように変化しましたか?
（5）「家族が続けて入り風呂の追い炊きをしない」など, 個別にではなく同居の方（ご家族など）みなさんで省 エネ行動に取り組む機会は, 診断前にくらべてどのよ うに変化しましたか?

回答方法は, (1)〜 (3) が「はい」「いいえ」の 2 択, (4), (5) が「増加した」「変わらない」「減少した」の3択による択一 式とした。

\subsection{4 電力消費量}

電力消費量については, HEMS (House Energy Management System）により，各世帯における電力消費量を1時間単位 で取得したデー夕を用いた。本データの取得期間は，世帯ご とに異なるが概ね 2011 年 11 月から 2012 年 3 月までであり, 診断実施前後の比較に用いるには十分なデー夕量とは言えな い。そのうえ, 取得期間に年末年始を含んでいることなどか ら, 電力消費量の集計において曜日や行事などの影響を排 除する必要がある。

このようなデータの特殊性を考慮し, 本研究では, 以下の ア〜エの条件に該当する 254 世帯のデー夕を抽出した。これ らのうち, ア, イは, 非日常的なデー夕を除外するため, ウ は，取得が不十分なデー夕を除外するための条件である。ま た，工は，診断受診前後で世帯員の増減などの変化があっ たと考えられる世帯を除外するために設定した。

ア土日祝日でないこと

イ 年末年始の期間中でないこと

(2011 年 12 月 29 日〜 2012 年 1 月 3 日)

ウ診断受診日の前 15 日，後 15 日それぞれにおいて, 3 日以上整備されていること

エ 診断受診後の電力消費量が, 受診前と比べて 2 倍以 上に増加, または 2 分の 1 以下に減少していないこと

これら 254 世帯は, 2011 年 12 月 19 日から 2012 年 2 月 5 日までの間にうちエコ診断を受診しており，うち1月中旬 (11 
〜20日）における受診世帯が 156 世帯であった。主な居住 地は, 東京都, 神奈川県及び千葉県が合わせて 118 世帯, 大阪府及び兵庫県が合わせて 63 世帯であった。

また, これらの 254 世帯については, うちエコ診断の受 診による影響の経過を確認するため, 診断受診日の後 16 30 日，31〜 45 日のデータについても抽出し，それぞれ 252 世帯, 233 世帯を分析に用いた。抽出にあたっては, 上記ア 〜エを条件とした。

なお, 取得したデー夕は, 世帯ごとの総電力消費量であり, 家電機器別などの内訳は取得していない。

\section{4 分析方法}

HEMS による電力消費量デー夕に基づき，対象世帯ごとの うちエコ診断受診前, 受診後における電力消費量 (日平均) を算出した。受診前から受診後にかけての増減を電力変化 量とし, 対象世帯ごとの電力変化量について, 家庭内コミュ ニケーションの状況により差異があるかを分析した。

なお，電力変化量は, 電力消費量 (日平均) が, 受診前 から受診後にかけて減少していればマイナス值, 増加してい ればプラス值とする。

\section{3. 結果と考察}

\section{1 うちエコ診断受診による電力消費量の変化}

図 2 は, 対象世帯ごとに求めた電力変化量を, 昇順に並 ベ替えて示したグラフである。対象の 254 世帯のうち, 電 力消費量の削減を達成した世帯は 119 世带, 未達成の世帯 は135世帯であった。省エネ行動を勧められたにも関わら ず, 電力消費量が増加した世帯の方が減少した世帯よりも多 くなっていることは，気温変化が影響していると考えられる。 分析に用いた 254 世帯の主な居住地として前述した 5 都府県 における1月中の日平均気温は，1月上旬から下旬にかけて 低下傾向にあった（図３）。つまり, 電力消費量が増加した 世帯が多かった主な要因として, 診断受診前に比べて, 受 診後の暖房需要等が増加したことが考えられる。

\section{2 家庭内コミュニケーションによる電力変化量の差異}

家庭内コミュニケーションの状況により対象世帯を 2 群に 分け, 各群の電力変化量の平均值に差異があるかを検証す るため, 有意水準を $5 \%$ として $\mathrm{t}$ 検定を行った。

図4に示されるように, 電力変化量は (1)〜（5）の全てに おいて, コミュニケーション有の世帯群, コミュニケーション 無の世帯群ともにプラス值となった。これは, どちらの世帯 群も平均的には, 診断前から診断後にかけて電力消費量が 増加していることを示している。要因としては, 前項で述べ たように日平均気温の低下による影響が考えられる（図３）。

なお，本項では，診断による電力消費量の削減効果を明 らかにすることを目的としておらず，コミュニケーションの違 いが与える影響について着目しているため, 気温補正をする ことなく分析を行う。この点に関連して, 二つの世帯群にお いて居住地域や診断日に偏りがないかを確認したところ, (1)
〜（5）の全てに共通して，偏りは見られなかった。

\subsection{1 診断内容の伝達による電力変化量の差異}

図 4 に示すように，(1)「うちエコ診断の診断内容を, 他の 同居の方 (ご家族など ) 一人以上に伝えましたか?」につい て,「はい」と回答をした世帯群と,「いいえ」と回答した世 帯群との間に, 電力変化量の有意な差異は見られなかった。

\subsection{2 買替行動に関するコミュニケーションによる電力変化 量の差異}

図 4 に示すように，買替行動に関する設問である (2)「ご 家庭内 (ご家族以外の同居している方も含む) において，家 電などの買い替えについて相談しましたか?」について,「は い」と回答した世帯群と,「いいえ」と回答した世帯群との 間では, 電力変化量に有意な差異が認められた。

有意な差異が確認された要因の一つとして, 買い替えに ついて家族で相談をした世帯は，そうでない世帯に比べて， 買い替えに至った世帯が多かった可能性がある。買い替え についての家庭内での相談が, 買い替えに係る意思決定や 世帯員間の合意形成を促したことで, 省エネ製品への買い替 えがなされたと推測される。この推測に関して, 診断から 1 , 2 か月後の事後調査で得られた, 買い替えの実施状況につ いて確認した。その結果, 買い替えについて家族で相談を した世帯群に占める買替実施世帯の割合が, 相談をしなかっ

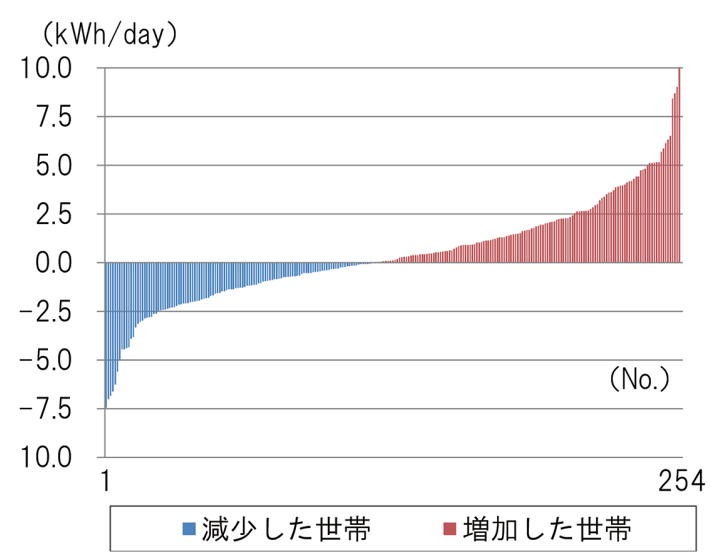

図2 うちエコ診断受診後の電力消費量の変化

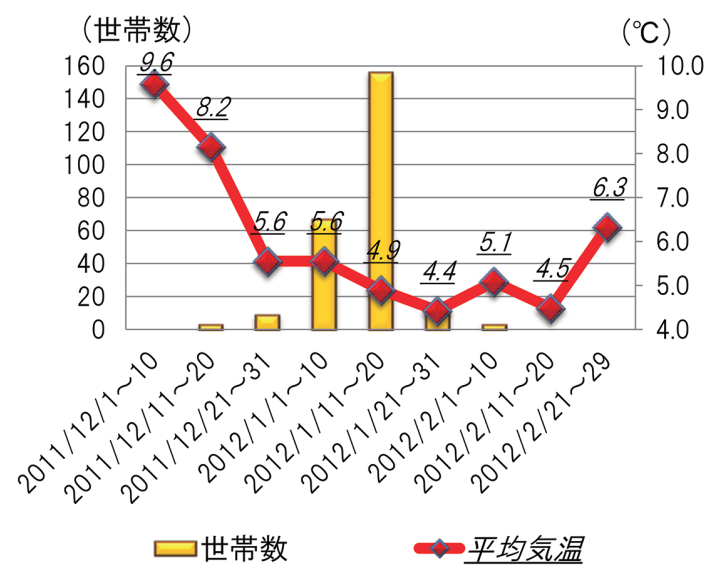

図3 うちエコ診断実施日と平均気温 


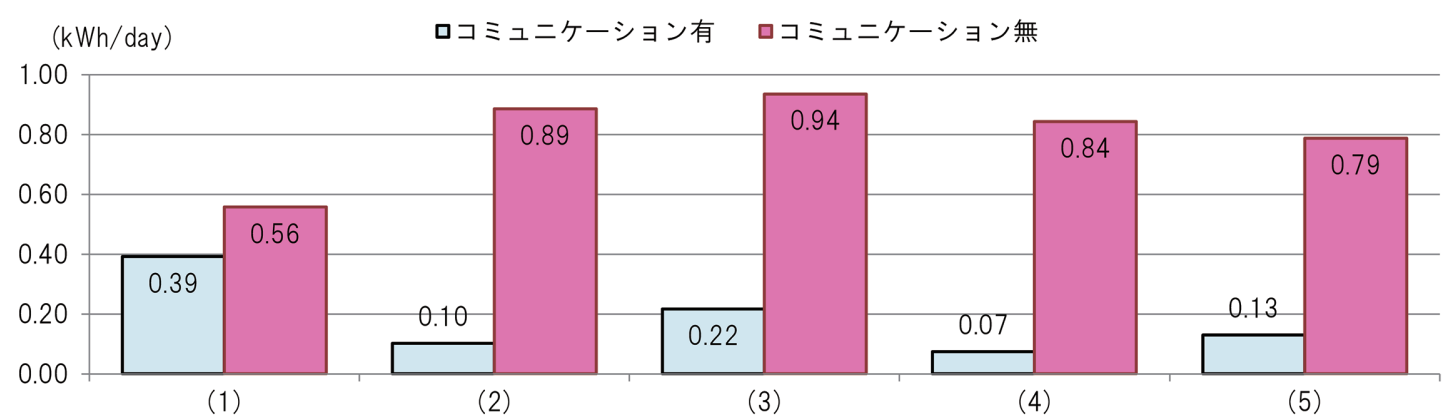

\begin{tabular}{|c|c|c|c|c|c|}
\hline \multirow{4}{*}{ (1) } & \multirow{4}{*}{$\begin{array}{l}\text { うちエコ診断の診断内容を、他の同居の方（ご家族など）一人以上 } \\
\text { に伝えましか？ }\end{array}$} & \multicolumn{2}{|c|}{ 単純集計 } & \multicolumn{2}{|c|}{ t検定 } \\
\hline & & した & 235 & t值 & -0.244 \\
\hline & & していない & 19 & 自由度 & 252 \\
\hline & & & & p值 & 0.808 \\
\hline \multirow{3}{*}{ (2) } & \multirow{3}{*}{$\begin{array}{l}\text { ご家庭内（ご家族以外の同居している方も含む）において、家電な } \\
\text { ごの賛えについて相談しましたか？ }\end{array}$} & した & 156 & t值 & -2.153 \\
\hline & & していない & 98 & 自由度 & 252 \\
\hline & & & & p值 & $0.032 *$ \\
\hline \multirow{3}{*}{ (3) } & \multirow{3}{*}{ 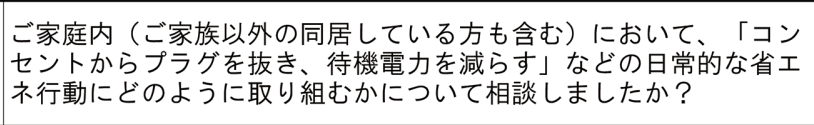 } & した & 188 & t值 & -1.770 \\
\hline & & していない & 66 & 自由度 & 252 \\
\hline & & & & p值 & 0.078 \\
\hline \multirow{3}{*}{ (4) } & \multirow{3}{*}{$\begin{array}{l}\text { ご家庭内（ご家族以外の同居している方も含む）で日常的な省エネ } \\
\text { 行動をきちんとと注施するよ同居の方（ご家族など）同士で注 } \\
\text { 意し合う機会は、診断前にくらべてどのように変化しましたか? }\end{array}$} & 増加した & 145 & t值 & -2.145 \\
\hline & & 変わらない & 107 & 自由度 & 252 \\
\hline & & 減少した & 2 & p值 & $0.033 *$ \\
\hline \multirow{3}{*}{ (5) } & \multirow{3}{*}{ 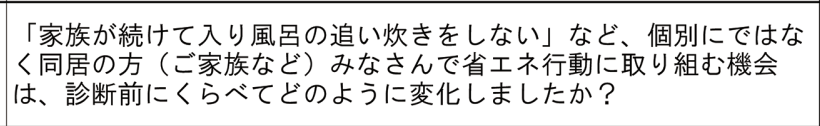 } & 増加した & 148 & t值 & -1.826 \\
\hline & & 変わらない & 103 & 自由度 & 252 \\
\hline & & 減少した & 3 & p值 & 0.069 \\
\hline
\end{tabular}

図4 電力変化量と家庭内コミュニケーションの関係性

た世帯群に占める買替実施世帯の割合と比べて高い傾向が 見られた。買替行動別に見て特に顕著だったのは照明器具 で「LED 照明に付け替える」では，相談をした 156 世帯の うち 32.7\% (51 世帯) が買い替えを実施していた。一方，相 談をしなかった 98 世带では，そのうち 19.4\% (19 世帯) が 買い替えを実施しており，買替実施世帯の割合は，相談をし た世帯が 13.3 ポイント高かった。同様に，相談をした世帯 のうち, エアコンの買い替えについては 5.3 ポイント, 冷蔵 庫の買い替えについては 11.0 ポイント, テレビの買い替えに ついては 6.2 ポイントが，相談をした世帯の方が買替実施世 帯の割合が高かった。

\subsection{3 日常的な省エネ行動に関するコミュニケーションによ る電力変化量の差異}

図 4の（3）～（5）は，日常的な省エネ行動に関するコミュ ニケーションと電力変化量の関連性に係る $\mathrm{t}$ 検定結果を示し ている。

(3)「ご家庭内 (ご家族以外の同居している方も含む) に おいて，『コンセントからプラグを抜き，待機電力を減らす』 などの日常的な省エネ行動にどのように取り組むかについて 相談しましたか?」について,「はい」と回答した世帯群と,「い いえ」と回答した世帯群との間に, 電力変化量の有意な差 異は見られなかった。

他方, 同じ日常的な省エネ行動に関するコミュニケーショ ンでも, (4)「ご家庭内 (ご家族以外の同居している方も含む)
で日常的な省エネ行動をきちんと実施するように，同居の方 （ご家族など）同士で注意し合う機会は，診断前にくらべて どのように変化しましたか?」については,「増加した」と回 答した世帯群と,「変わらない」または「減少した」と回答し た世帯群との間に, 電力変化量の有意な差異が認められた。 両世帯群に違いが生じた要因としては, 注意し合う機会が 増加したことで, より多くの世帯員が省エネ行動の実施者と なり, 結果として世帯全体の電力消費量が減少した可能性 がある。

最後に，(5)「『家族が続けて入り風呂の追い炊きをしない』 など，個別にではなく同居の方（ご家族など）みなさんで省 エネ行動に取り組む機会は，診断前にくらべてどのように変 化しましたか?」については,「増加した」と回答した世帯群と, 「変わらない」または「減少した」と回答した世帯群の間では, 電力変化量に一定の差異は認められたが, 有意な差異でな かった。この要因の一つとして, 対象世帯の多くが, 節電行 動（例えば，家族が同じ部屋で過ごす）をイメージすること なく，具体例に挙げている風呂の追い炊きについて回答した 可能性が挙げられる。その場合, オール電化でない世帯では, 主にガス消費量の削減をもたらすものであり,「増加した」と 回答した世帯の電力消費量は必ずしも減少しない。これに 関連して, 対象世帯の消費エネルギーの種類を確認したとこ ろ, 254 世帯のうちガス給湯世帯が 211 世帯を占めていた。 
3.3 家庭内コミュニケーションによる電力変化量の差異の 経日変化

次に, 家庭内コミュニケーションによる電力変化量の差異 について, 経日変化を確認するための分析を行った。前節と 同様に，うちエコ診断受診後 16〜30日間， 31〜 45日間 の電力消費量 (日平均) を算出し, 受診前 15 日間の電力消 費量 (日平均) に対する増減を電力変化量とした。前節にお いて電力変化量に統計的に有意な差異が認められた 2 種の 家庭内コミュニケーション (2) と (4) を対象とし, コミュニケー ションの状況により分けた 2 世带群の電力変化量の間に, 継 続的に差異が認められるかを検証するために，3.2 節と同様 に, 有意水準を $5 \%$ として $\mathrm{t}$ 検定を実施した。分析結果を図 5 , 図6に示す。

これらのグラフのうち，診断受診後 $1 \sim 15$ 日間及び 16

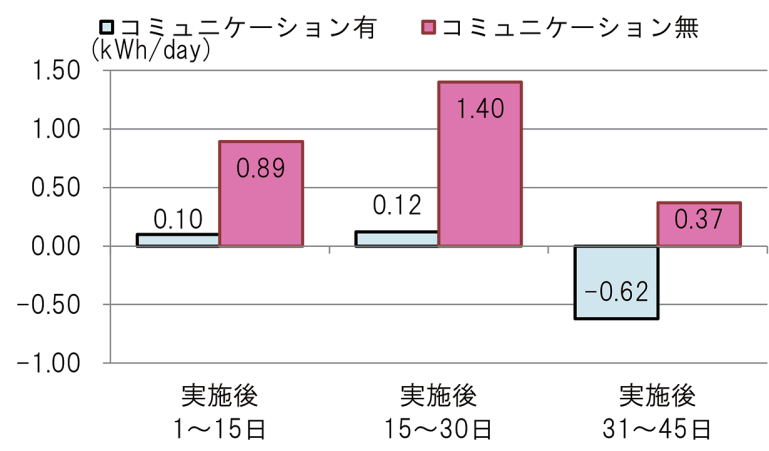

\begin{tabular}{|c|c|c|c|c|}
\hline & & $\begin{array}{c}\text { 実施後 } \\
1 \sim 15 \text { 日 }\end{array}$ & $\begin{array}{c}\text { 実施後 } \\
15 \sim 30 \text { 日 }\end{array}$ & $\begin{array}{c}\text { 実施後 } \\
31 \sim 45 \text { 日 }\end{array}$ \\
\hline \multirow{3}{*}{ (2) } & $\mathrm{t}$ t值 & -2.153 & -3.130 & -2.068 \\
\hline & 自由度 & 252 & 250 & 231 \\
\hline & p值 & $0.032 *$ & $0.002 * *$ & $0.040 *$ \\
\hline
\end{tabular}

図5 電力変化量と

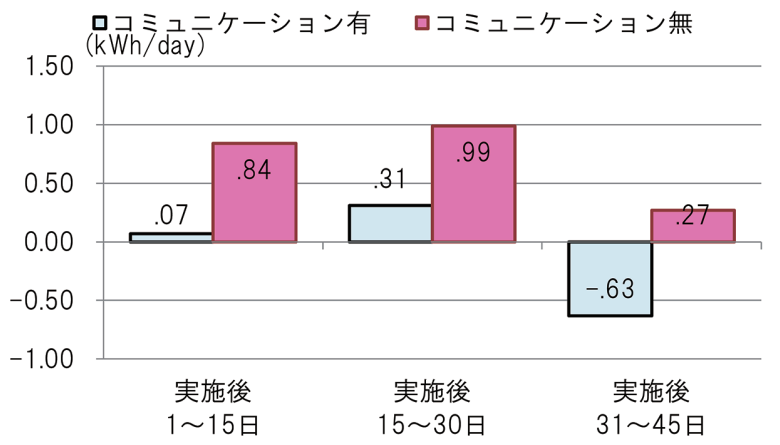

\begin{tabular}{|c|c|c|c|c|}
\hline & & $\begin{array}{c}\text { 実施後 } \\
1 \sim 15 \text { 日 }\end{array}$ & $\begin{array}{c}\text { 実施後 } \\
15 \sim 30 \text { 日 }\end{array}$ & $\begin{array}{c}\text { 実施後 } \\
31 \sim 45 \text { 日 }\end{array}$ \\
\hline \multirow{3}{*}{ (4) } & $\mathrm{t}$ 值 & -2.145 & -1.665 & -1.906 \\
\hline & 自由度 & 252 & 250 & 231 \\
\hline & $p$ 值 & $0.033 *$ & 0.097 & 0.058 \\
\hline
\end{tabular}

30 日間における電力変化量は, 図 4 と同様にプラス值であっ た。一方で, 診断受診後 $31 \sim 45$ 日間における電力変化量 は，コミュニケーション有の世帯群のみマイナス值となった。 これについても, 気温の変化が影響していると考えられる（図 3)。このことに留意して, 両世帯群の間に電力変化量の平 均値の差異が認められるかを検証した結果を示す。

\subsection{1 買替行動に関するコミュニケーションによる電力変化 量の差異の経日変化}

図 5 に示すように，(2)については，受診後 1〜 15 日，受 診後 16〜30日及び受診後 31〜45日の全ての期間で,「はい」 と回答をした世帯群と,「いいえ」と回答した世帯群との間で, 電力変化量に有意な差異が確認された。

前節において，買い替えについて家族で相談をした世帯 は，相談しなかった世帯に比べて，買替行動を実施した世 帯比率が高いことを確認した。受診後 1〜15日間に打ける 電力変化量の有意な差異が買替行動の実施によるものであ るとすれば，その効果は受診後 16 日目以降も継続すると考 えられる。

3.3.2 日常的な省エネ行動に関するコミュニケーションによ る電力変化量の差異の経日変化

図6に示すように，(4)について，「増加した」と回答した 世帯と,「変わらない」または「減少した」と回答した世帯と の間で, 電力変化量の有意な差異が認められるのは, 前節 で示した受診後 1〜15 日の期間のみであった。受診後 16 30 日及び受診後 $31 \sim 45$ 日の期間では, 両世帯群の電力変 化量に有意な差異は見られなかった。しかし，受診後 45 日 までの全ての期間において, 有意確率 ( $\mathrm{p}$ 值) は 10\%未満 であった。

日常的な省エネ行動による電力消費量の削減は，世帯員 による継続的な実施が必要となる。受診後 1 15 日間にお ける電力変化量の有意な差異が省エネ行動の実施によるも のとした場合，受診による行動変容の効果が時間の経過と ともに衰退に向かう傾向があったと考えられる。しかし，そ のような傾向の中においても, 互いに注意し合うコミュニケー ションが, 日常的な省エネ行動の実施の持続を助ける一定 の働きをした可能性がある。

\section{4 省エネ行動の規定因と家庭内コミュニケーションとの 関係性}

ここまで, 電力変化量と家庭内コミュニケーションの関係 性について述べてきた。3.2, 3.3 の分析の結果から, 家庭 内コミュニケーションは, 各家庭における電力消費量に何か しらの影響を与えているように見える。しかし，その影響を 明らかにするためには，他の世帯属性による影響を確認する 必要がある。

既往研究においては, 家庭内での省エネ行動に影響を与 える世帯属性の中でも, 特に世帯年収, 世帯人数の 2 要素 について言及している研究が散見される6) 8)。そこで, 本項 では, これら2要素が交絡因子となっている可能性について 確認した。 
表2 世帯年収，世帯人数と家庭内コミュニケーションの関係性

\begin{tabular}{l|c|c|c|c|c}
\hline \multirow{2}{*}{ 世帯年収 } & \multirow{2}{*}{ 度数 } & \multicolumn{2}{|c|}{$(2)$} & \multicolumn{2}{|c}{$(4)$} \\
\cline { 3 - 6 } & & 有 & 無 & 有 & 無 \\
\hline$\sim 500$ 万円 & 23 & $14(61 \%)$ & $9(39 \%)$ & $14(61 \%)$ & $9(39 \%)$ \\
\hline $500 \sim 1000$ 万円 & 161 & $97(60 \%)$ & $64(40 \%)$ & $95(59 \%)$ & $66(41 \%)$ \\
\hline 1000 万円〜 & 55 & $36(65 \%)$ & $19(35 \%)$ & $29(53 \%)$ & $26(47 \%)$ \\
\hline
\end{tabular}

(2) $: \mathrm{X}^{2}(2)=.474$, n.s. $\quad(4): \mathrm{X}^{2}(2)=.764$, n.s.

\begin{tabular}{l|l|c|c|c|c}
\hline \multirow{2}{*}{ 世带人数 } & \multirow{2}{*}{ 度数 } & \multicolumn{2}{|c|}{$(2)$} & \multicolumn{2}{c}{$(4)$} \\
\cline { 3 - 6 } & & 有 & 無 & 有 & 無 \\
\hline 2人 & 64 & $34(53 \%)$ & $30(47 \%)$ & $39(61 \%)$ & $25(39 \%)$ \\
\hline 3人 & 79 & $59(75 \%)$ & $20(25 \%)$ & $46(58 \%)$ & $33(42 \%)$ \\
\hline 4 人 & 75 & $43(57 \%)$ & $32(43 \%)$ & $39(52 \%)$ & $36(48 \%)$ \\
\hline 5 人 & 29 & $16(55 \%)$ & $13(45 \%)$ & $17(59 \%)$ & $12(41 \%)$ \\
\hline 6 & 5 & $3(60 \%)$ & $2(40 \%)$ & $2(40 \%)$ & $3(60 \%)$ \\
\hline
\end{tabular}

(2) : $\mathrm{X}^{2}(4)=8.741$, n.s., (4) $: \mathrm{X}^{2}(4)=1.830$, n.s.

家庭内コミュニケーション (2) 及び (4) が, 世帯年収，世 帯人数と相関があるかについて確認するために，有意水準を 5\%としてカイ二乗検定を行った結果を表 2 に示す。

世帯年収に関しては,「500 万円未満」「500 万円以上 1,000 万円未満」「1,000万円以上」の 3 択により取得されたデー夕 を用い，件数は，「500万円以上 1,000 万円未満」が最も多 く 161 件であった。これらの3グループにおいて, 家庭内コ ミュニケーションの有無の比率に違いがあるかを検定したと ころ, 有意な差異は確認されなかった。

世帯人数は，二人から六人までとなっており，件数は，三 人が最も多く 79 件であった（単身世帯は分析対象から除 外)。これらの 5 グループについて，家庭内コミュニケーショ ンの有無の比率に違いがあるかを検定したところ，有意な差 異は確認されなかった。

以上の分析から，家庭内コミュニケーションは，世帯年収 ならびに世帯人数とは関係しない世帯の特徵を表すひとつの 要素であり, 電力消費量の削減に寄与する可能性が示唆さ れる。

\section{4. まとめ}

本研究は，家庭内コミュニケーションが，家庭における省 エネルギー行動の実施に影響を与えているか否かを明らかに することを目的とし，「うちエコ診断」受診世帯を対象に取 得された実測值に基づき統計的手法を用いて分析した。

分析の結果，家庭内に拈けるコミュニケーションの実施状 況に係る一部の設問においては，その実施有無等による電 力変化量の平均值に有意な差異が認められた。具体的には, 受診後に省エネ製品への買い替えについて家庭内で相談し た世帯は，そうでない世帯に比べ，受診後に電力消費量が 少ない傾向にある。また，日常的な省エネ行動の実施につ いて世帯員同士が互いに注意し合う頻度が受診後に増えた 世帯は，そうでない世帯に比べて，受診後の電力消費量が 少ない傾向にある。つまり, このようなコミュニケーションが, 家庭に拈ける省エネ行動（買替行動も含む）を促している可
能性がある。

続いて，本研究の課題を述べる。先に述べたように，本 研究におけるデー夕取得は，環境省の「うちエコ診断」事業 の中で行った。事業の本流の妨げとならないよう, 調査内容 を短期間で最小限に絞り込む必要があったことなどから，本 研究においてはいくつかの課題を残している。

まず，家庭内コミュニケーションに係る調査・分析におい ては, 省エネ行動への介入 (本研究においてはうちエコ診断) とコミュニケーションとの因果関係を明確化する必要がある。 具体的には, 本研究に拈けるコミュニケーション有の世帯が, うちエコ診断の受診を契機に，省エネ行動に係るコミュニ ケーションをとったかどうかが不明確である。また，もとも とコミュニケーションを頻繁にとる世帯かどうかも，コミュニ ケーションの有無に影響を与える要素となる。今後は, 以上 の点に留意し，家庭内コミュニケーションに係る質問項目の 設定や調査方法を検討したい。

次に, 日常生活での省エネ行動に影響を与える可能性が ある他の規定因と，家庭内コミュニケーションとの関係性を 十分に精査できていない点が挙げられる。これは, 本研究 に㧍ける結果が，家庭内コミュニケーションの有無ではなく， 他の要因で生じた可能性を残していることと同義である。世 帯年収と世帯人数に関しては, 家庭内コミュニケーションと の間に有意な関係が認められなかったが，それら以外の世 帯属性 (年齢, 居住地域, 住宅の広さなど) も含めて改めて 検証を行う必要がある。また，対象世帯が有する環境に対 する意識や知識についても，考慮すべきである。

さらに, 本研究の分析は, 環境省が実施する「うちエコ 診断」事業に参加・協力した世帯を対象として行っているた め,もともと環境に対する意識が高い世帯であった可能性が ある。

以上のように，対象世帯の属性を多面的に捉え，それらの 要素を測定·分析の対象としたうえで, 家庭内コミュニケーショ ンの影響に関してさらに詳しく分析することが求められる。 今後, 家庭内のコミュニケーションが省エネルギー行動に 
与える影響を明らかにすることは，介入を受けた世帯が，省 エネルギー行動の継続的な実施や省エネルギー化の実現に たどり着くまでのメカニズムを紐解くことにつながると考元 る。このことが, より効果的な家庭用エネルギー診断ツール の開発や属性の異なる個々の世帯に適合した提言・アドバイ スなど，家庭の省エネルギー化に向けた介入方法の検討に 資するものと考元れる。

\section{謝 辞}

データの取得にご協力戴いた，環境省ならびに凸版印刷 株式会社の皆様に深く御礼申し上げる。

\section{文 献: References}

1) McCalley, L. T.; Midden, C. J. H., Journal of Economic Psychology, 23, 589-603 (2002)

2) McMakin, A. H.; Malone, E. L.; Lundgren, R. E., Environment and Behavior, 34(6), 848-863 (2002)
3) Staats, H. J.; Wit, A. P.; Midden, C. Y. H., Journal of Environmental Management, 45, 189-203 (1996)

4) Staats, H.; Harland, P.; Wilke, H. A. M., Environment and Behavior, 36(3), 341-367 (2004)

5) Abrahamse, W.; Steg, L.; Vlek, C.; Rothengatter, T, Journal of Environmental Psychology, 25, 273-291 (2005)

6) Clark, C. F.; Kotchen, M. J.; Moore, M. R., Journal of Environmental Psychology, 23, 237-246 (2003)

7) Yagita, Y.; Iwafune, Y., Journal of Japan Society of Energy and Resources, 32(4), 25-33 (2011) : 八木田克英, 岩船由 美子, エネルギー・資源学会論文誌 , 32(4), 25-33 (2011)

8) Gram-Hanssen, K., Energy Efficiency, 6(3), 447-457 (2012), DOI :10.1007/s12053-012-9184-4

9) Kikui, J.; Kawahara, H., Life and Environment, 56(2), 2730 (2011) : 菊井順一, 川原博満, 生活と環境, 56(2), 27-30 (2011) 